\title{
SCF promotes the production of IL-13 via the MEK-ERK-CREB signaling pathway in mast cells
}

\author{
YIMENG WANG $^{1}$, HUA MA $^{1}$, XIANGNAN TAO ${ }^{1}$, YULAN LUO $^{1}$, HELONG WANG $^{1}$, \\ JING HE $^{1}$, QIANG FANG ${ }^{2}$, SHUJUN GUO ${ }^{1}$ and CHUANWANG SONG ${ }^{1}$ \\ Departments of ${ }^{1}$ Immunology and ${ }^{2}$ Microbiology and Parasitology, \\ Bengbu Medical College, Bengbu, Anhui 233030, P.R. China
}

Received March 4, 2018; Accepted July 12, 2018

DOI: $10.3892 /$ etm.2019.7866

\begin{abstract}
Mast cells serve a key role in the occurrence and development of allergy. As an important growth factor of mast cells, stem cell factor (SCF) has an effect on the apoptosis, chemotaxis, adhesion, degranulation and other biological characteristics of mast cells. However, there are few studies regarding the effect of SCF signal on the production of cytokines from mast cells, particularly Th2 type cytokines. In the present study, the expression and secretion of IL-13 in P815 cells stimulated by SCF were detected by fluorescence quantitative PCR and ELISA, and western blotting and EMSA were used to detect ERK phosphorylation and activation of CREB in stimulated P815 cells. The results demonstrated that the production of IL-13 was significantly increased in P815 cells stimulated by SCF $(1-100 \mathrm{ng} / \mathrm{ml} ; \mathrm{P}<0.01)$. There was an obvious phosphorylation of ERK and CREB activation in P815 cells stimulated by SCF (50 ng/ml). Compared with the SCF single stimulation group, the production of IL-13 was significantly reduced in P815 cells stimulated with U0126 (ERK-MEK/pathway inhibitor) or H-89 (CREB inhibitor) combined with SCF stimulation group $(\mathrm{P}<0.01)$. However, JSI-124 (JAK/STAT3 pathway inhibitor), Wortmannin (PI3K/Akt pathway inhibitor) and PDTC (NF- $\kappa \mathrm{B}$ inhibitor) had no effect on the role of SCF promoting the P815 cells producing IL-13. Therefore, SCF signaling promotes mast cell P815 to produce IL-13, and this effect is associated with the MEK-ERK-CREB signaling pathway.
\end{abstract}

\section{Introduction}

Mast cells (MCs) are important effector cells and immune regulatory cells in vivo (1). It originates from hematopoietic stem cells in bone marrow, matures in the peripheral tissues,

Correspondence to: Dr Chuanwang Song, Department of Immunology, Bengbu Medical College, 2600 Donghai Avenue, Bengbu, Anhui 233030, P.R. China

E-mail: chuanwangsong@163.com

Key words: stem cell factor, mast cells, interleukin 13 distributes in the mucosa and connective tissue of whole body $(2,3)$. MCs were mainly divided into mucous membranes and connective tissue MCs two subgroups according to the distribution site and particles containing tryptase or chymase (4). Many stimulus may activate the MCs through the FceRIdependent and non-dependent (such as c-Kit, TLR) way. Activated MCs can produce three types of effector molecules: The first is material stored in particles, such as 5-HT, histamine, tryptase and chymase; the second category is the new synthetic substances such as lipid metabolites, prostaglandins; the third category is cytokines, such as IL-1, 3 , TNF- $\alpha$, VEGF and so on (5-7). It is precisely because of the generation of so many types of effector molecules, so MCs can participate in a variety of biological processes of body. Now studies show that MCs play a key role in the development of allergy $(8,9)$. Stem cell factor (SCF) (i.e. c-Kit ligand), an important growth factor, has soluble and membrane-bound two forms. SCF can be produced from both fibroblasts and endothelial cells in vivo $(10,11)$. MCs characteristically express SCF receptor c-Kit. SCF is a potential growth factor of MCs, in addition to affecting the development of MCs, but also on its apoptosis, chemotaxis, adhesion, degranulation and other biological characteristics $(12,13)$. But there are few studies on the effect of SCF signal on the production of cytokines (especially Th2 type cytokines) in MCs. In the present study, we investigated the effects of SCF on the production of IL-13 and its mechanisms in mouse mast cell line P815 cells.

\section{Materials and methods}

Cell lines and experimental reagents. Mouse mast cell line P815 cells purchased from Shanghai Institute of life sciences, Chinese Academy of sciences. DMEM (high glucose type) culture was purchased from Thermo Fisher Company. Fetal bovine serum is product of Hangzhou Sijiqing biological company. Fluorescein (PE-Cy5)-labeled CD117 (c-Kit) antibody was purchased from eBioscience company. Recombinant mouse SCF and U0126 was respectively purchased from PeproTech and Gene Operation. JSI-124 and Curcumin are the product of Sigma company. Wortmannin, NP-40 lysate, $\beta$-actin, p42/44 antibody, Phospho-p42/44 antibody, horseradish peroxidase labeled goat anti-mouse IgG antibody, the BCA Protein Assay kit, nuclear proteins and cytoplasmic protein extraction 
kit, H-89, PDTC, chemiluminescent EMSA kit, biotin-labeled EMSA probes of CREB were purchased from Beyotime Institute of Biotechnology (Haimen, China). Mouse Interleukin 13 (IL-13) ELISA kit was purchased from Wuhan Huamei Biological Engineering Co., Ltd. Trizol Reagent was purchased from Invitrogen Corporation. TransScript First-Strand cDNA Synthesis SuperMix and TransStart Top Green qPCR SuperMix are products of Transgen Biotech company.

Cell culture. P815 cells were suspended in DMEM complete solution (containing $4.0 \mathrm{mM}$ L-glutamine, $4500 \mathrm{mg} / 1$ glucose, $10 \%$ fetal bovine serum, 50,000 U/1 gentamicin, $1 \mathrm{mmol} / \mathrm{l}$ sodium pyruvate), and cultured in $37^{\circ} \mathrm{C}, 5 \% \mathrm{CO}_{2}$ incubator. P815 cells were seeded in 24-well plates and cells density is $5 \times 10^{5}$ cells $/ \mathrm{ml}$. After cultured in DMEM without serum for starvation $12 \mathrm{~h}$, the cells were treated with different concentrations of SCF for different time.

Detection of c-kit receptor on P815 cell surface by flow cytometry. The cultured cells were washed 2 times with the staining buffer solution. P815 cells were incubated with PE-Cy5-c-Kit antibody (concentration based on the specification instruction) in $100 \mu 1$ reaction system at dark $4^{\circ} \mathrm{C}$. After washed two times with staining buffer, stained cells were fixed with $1 \%$ paraformaldehyde (PFA), then were detected by flow cytometry.

Reverse transcription-quantitaive polymerase chain reaction (RT-qPCR). After P815 cells were washed two times with PBS, their total RNA was extracted using Trizol reagent. cDNA was reversed to synthesized in accordance with manufacturer's instructions. PCR amplification was conducted in $25 \mu \mathrm{l}$ reaction system (including 2xTS Top Green qPCR SuperMix $12.5 \mu 1$, Passive Reference Dye $0.5 \mu 1$, cDNA $1 \mu 1$, Forward Primer $0.5 \mu 1$, Reverse Primer $0.5 \mu 1$, RNase-free water $10 \mu \mathrm{l}$ ). PCR reaction conditions (two step method): $94^{\circ} \mathrm{C} 30 \mathrm{~s}, 94^{\circ} \mathrm{C} 5 \mathrm{~s}$, $60^{\circ} \mathrm{C} 30 \mathrm{~s}$, a total of 40 cycles. IL-13 primer sequences are listed below: Upstream primer: 5'-GCAGCAGCTTGAGCACAT T-3', downstream primer: 5'-GGCATAGGCAGCAAACCA-3'. Gene expression was analyzed using $2^{-\triangle \Delta C q}$ method (14).

ELISA. To collect the culture supernatant of P815 cells under various conditions, the concentration of IL-13 in supernatant was detected by ELISA according to manufacturer's instructions.

Western blot analysis. Cytoplasmic protein was extracted from P815 cells of control group and SCF stimulation group according to manufacturer's instructions. After quantified by BCA method, the protein was electrophoresed by SDS-PAGE (10\% separating gel and 5\% stacking gel). After electrophoresis, NC film was used to transfer the protein. The membrane was blocked $2 \mathrm{~h}$ with $5 \%$ BSA, and washed 30 min using TBST, then the membrane was incubated with primary antibody or loading control antibody overnight at $4^{\circ} \mathrm{C}$. After the membrane was washed $30 \mathrm{~min}$ with TBST, then was incubated with HRP-labeled second antibody $2 \mathrm{~h}$. The positive signal was detected by chemiluminescence method, and then the light density analysis was carried out.

Electrophoretic mobility shift assay (EMSA). Cell nuclear proteins were collected from P815 cells in the control group and the SCF stimulation group and biotin-labeled CREB probe and nuclear protein binding reaction was detected according to Beyotime kit instructions. Probe and protein mixture was electrophoresis $45 \mathrm{~min}$ at $120 \mathrm{~V}$ using $12 \%$ non-denaturing PAGE gel. After electrophoresis, the protein was transferred to nylon membrane using $380 \mathrm{~mA}$ constant current for $1 \mathrm{~h}$ and was cross-linked 10 min using ultraviolet rays. Enhanced chemiluminescence method was used for the detection of biotin labeled CREB probes. CREB consensus oligo sequences are as follows:

\section{5'-AGAGATTGCCTGACGTCAGAGAGCTAG-3', 3'-TCTCTAACGGACTGCAGTCTCTCGATC-5'.}

Statistical analysis. The experimental data is indicated as mean \pm standard deviation, and one-way analysis of variance was used with the Least Significant Difference post hoc test for the comparison between groups. All analyses were carried out using SPSS 16. $\mathrm{P}<0.05$ was considered to indicate a statistically significant difference.

\section{Results}

Expression of c-Kit receptor on the surface of mast cell P815. $\mathrm{SCF}$ corresponding receptor is c-Kit. To investigate the effect of SCF signal on mast cell, we first used flow cytometry to detect the expression of c-Kit in P815 cells. Result as shown in Fig. 1, almost all of the P815 cells membrane surface express c-Kit.

Effect of SCF on IL-13 production in P815 cells. P815 cells were stimulated $6 \mathrm{~h}$ with different concentrations of SCF. The supernatant in culture well was detected by ELISA, and the results were shown in Fig. 2. SCF (1-100 ng/ml) can promote P815 cells to produce IL-13, among which the $10-50 \mathrm{ng} / \mathrm{ml}$ effect is the most obvious. After P815 cells were stimulated with SCF (50 ng/ml) 6 h, IL-13 gene expression in P815 cells is increased by about 3-fold (Fig. 3). P815 cells were stimulated with SCF $(50 \mathrm{ng} / \mathrm{ml})$ at different times, the content of IL-13 in supernatant are shown in Fig. 4. Among them, the production of IL-13 reachs a higher level when P815 cells were stimulated 6-24 h.

SCF promotes the production of IL-13 in MCs by MEK-ERK signaling pathway. After pretreated $30 \mathrm{~min}$ with MEK/ERK pathway inhibitor U0126 $(10 \mu \mathrm{M})$ or JAK/STAT3 pathway inhibitor JSI-124 (100 nM) or PI3K/Akt pathway inhibitor wortmannin $(1 \mu \mathrm{M}), \mathrm{P} 815$ cells were stimulated $6 \mathrm{~h}$ with SCF $(50 \mathrm{ng} / \mathrm{ml})$, then the content of IL-13 in the culture supernatant of P815 cells was detected by ELISA. The results are shown in Fig. 5. U0126 completely blocked the effect of SCF on promotion IL-13 production in P815 cells, but JSI-124 and Wortmannin had no effect on this role of SCF. To demonstrate the activation of the MEK-ERK signaling pathway, cytosolic proteins was extracted from P815 cells stimulated with SCF (50 $\mathrm{ng} / \mathrm{ml})$ at different times and the activation of Erk1/2 was detected by Western blot (Fig. 6). Erk1/2 phosphorylation was the maximum in P815 cells stimulated 30 min with SCF. So it can be proved that the SCF signal can promote the production of IL-13 by activating the MEK-ERK signaling pathway in P815 cells. 

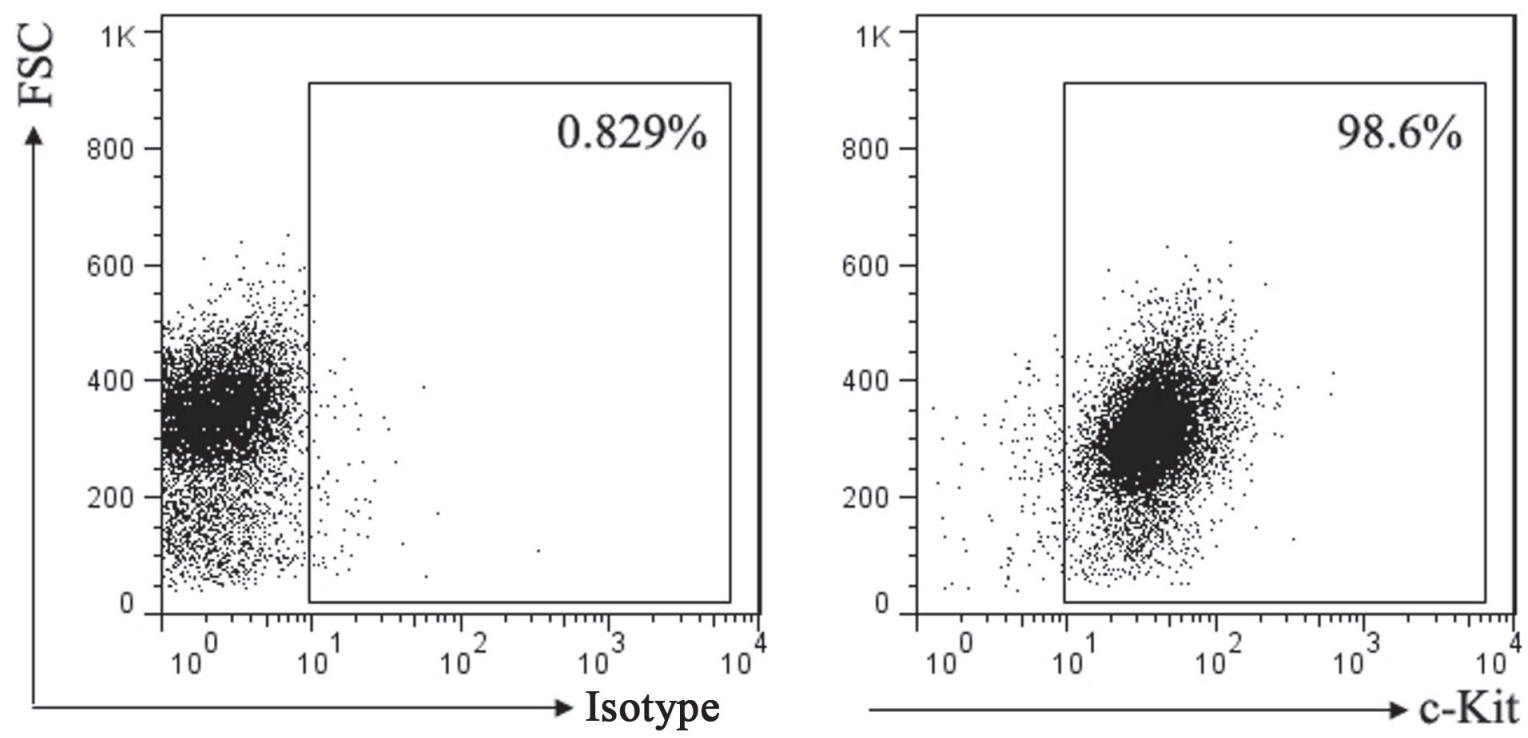

Figure 1. Expression of c-Kit receptor on the surface of P815 cells was detected by flow cytometry. FSC, forward scatter.

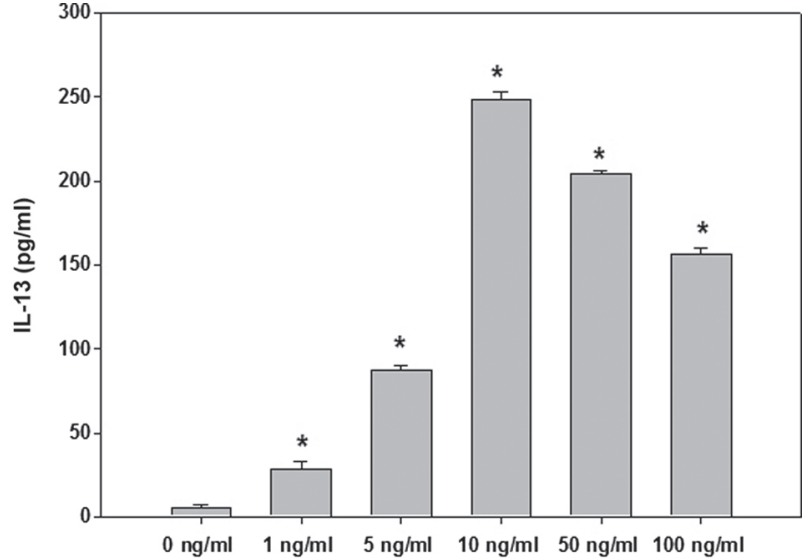

Figure 2. Content of IL-13 in supernatant of P815 cells stimulated by SCF. P815 cells were seeded in 24-well plates at a density of 5x105/ml. After P815 cells were stimulated for $6 \mathrm{~h}$ by different concentrations of SCF $(1-100 \mathrm{ng} / \mathrm{ml})$, the content of IL-13 in the supernatant of P815 cells was detected by ELISA. ${ }^{*} \mathrm{P}<0.01 \mathrm{vs} .0 \mathrm{ng} / \mathrm{ml}$. IL-13, interleukin 13; SCF, stem cell factor.

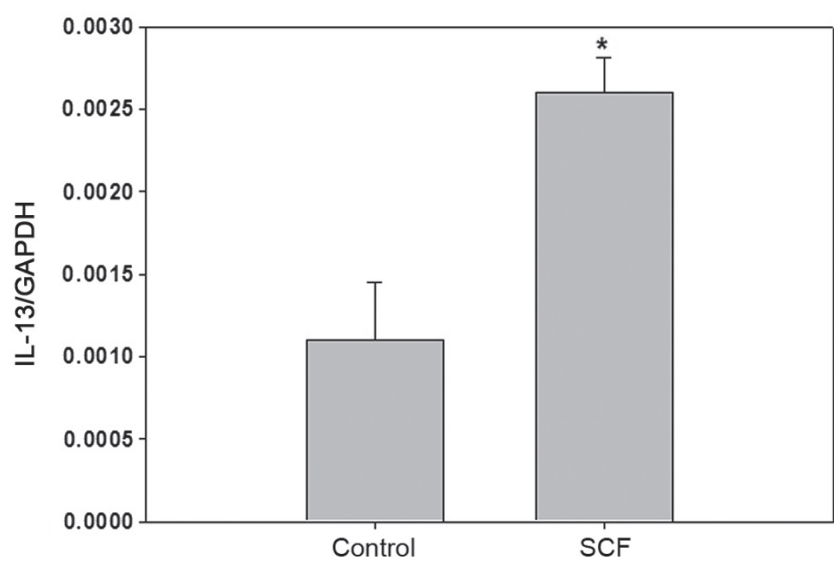

Figure 3. IL-13 gene expression of P815 cells stimulated by SCF. P815 cells (cell density, $5 \times 10^{5} / \mathrm{ml}$ ) were seeded in 24 -well plates. After P815 cells were stimulated for $6 \mathrm{~h}$ with SCF $(50 \mathrm{ng} / \mathrm{ml})$, the IL-13 gene expression of P815 cells was detected by reverse transcription-quantitative PCR. ${ }^{*} \mathrm{P}<0.01$. IL-13, interleukin 13 ; SCF, stem cell factor.

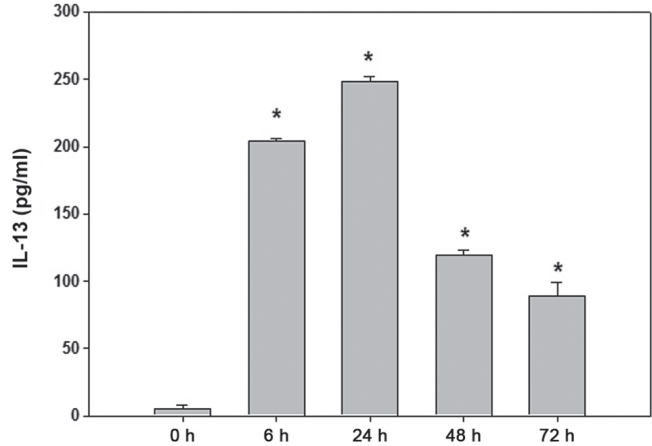

Figure 4. Secretion of IL-13 in supernatant of P815 cells stimulated different time by SCF $(50 \mathrm{ng} / \mathrm{ml})$. P 815 cells (cell density, $5 \times 10^{5} / \mathrm{ml}$ ) were seeded in 24-well plates. After P815 cells were stimulated 6, 24, 48 or $72 \mathrm{~h}$ with SCF $(50 \mathrm{ng} / \mathrm{ml})$, the content of IL-13 in the supernatant of P815 cells was detected by ELISA. ${ }^{\mathrm{P}}<0.01$ vs. 0 h group. IL-13, interleukin 13 ; SCF, stem cell factor.

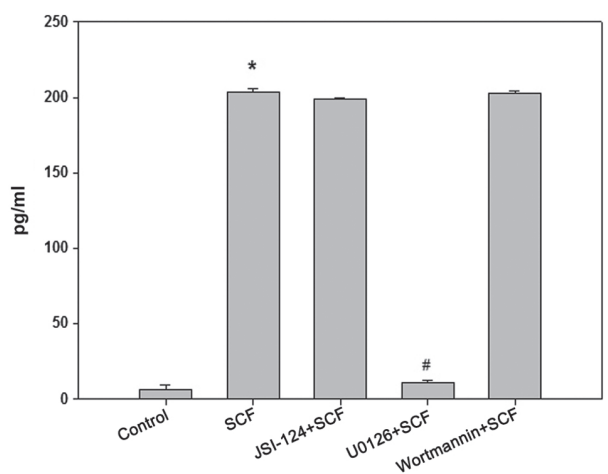

Figure 5. SCF signaling promotes P815 cells to secrete IL-13 via the MEK-ERK signaling pathway. P815 cells (cell density, $5 \times 10^{5}$ cells $/ \mathrm{ml}$ ) were seeded in 24-well plates. After pretreatment for 30 min with $\mathrm{U} 0126(10 \mu \mathrm{M})$, JSI-124 $(100 \mathrm{nM})$ or Wortmannin $(1 \mu \mathrm{M}), \mathrm{P} 815$ cells were stimulated for $6 \mathrm{~h}$ with SCF $(50 \mathrm{ng} / \mathrm{ml})$, then the content of IL-13 in the culture supernatant of P815 cells was detected by ELISA. 'Control' means P815 cells stimulated with dissolution medium. 'SCF' refers to P815 cells stimulated with $50 \mathrm{ng} / \mathrm{ml}$ SCF. 'JSI-124/U0126/Wortmannin'+SCF' means P815 cells pretreated for 30 min with JSI-124, U0126 or Wortmannin, followed by stimulation with $50 \mathrm{ng} / \mathrm{ml} \mathrm{SCF} .{ }^{\text {" }} \mathrm{P}<0.01$ vs. control; ${ }^{\#} \mathrm{P}<0.01$ vs. SCF. IL-13, interleukin 13; $\mathrm{SCF}$, stem cell factor. 
A

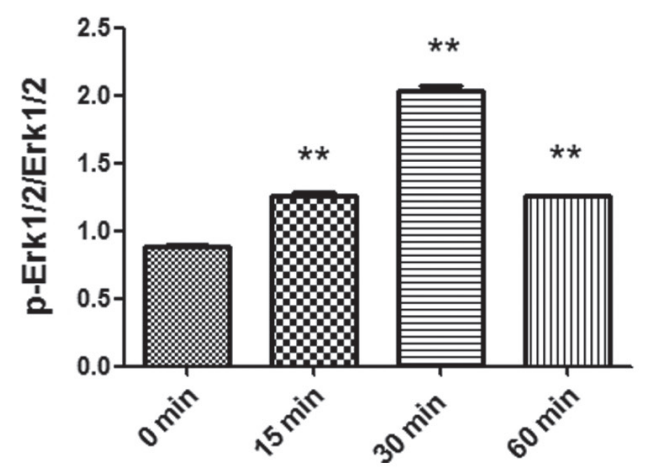

B

p-Erk $1 / 2$

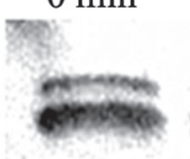

$15 \mathrm{~min} \quad 30 \mathrm{~min}$

$60 \mathrm{~min}$

Erk1/2
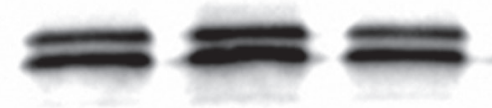

GAPDH

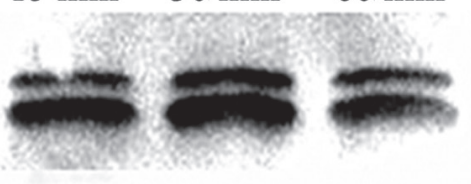

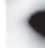

Figure 6. Effect of SCF signaling on the phosphorylation of ERK in P815 cells. P815 cells (cell density, 5x10 5 cells/ml) were seeded in 24 well plates. P815 cells were stimulated 0,15,30 and $60 \mathrm{~min}$ with SCF (50 ng/ml). Subsequently, cytoplasmic proteins were extracted. The phosphorylation of ERK1/2 in cytoplasmic proteins of P815 cells was detected by western blotting. (A) Statistical graph based on densitometric analysis and (B) representative blot. ${ }^{* *} \mathrm{P}<0.01$ vs. 0 min. p-, phosphorylated. SCF, stem cell factor.

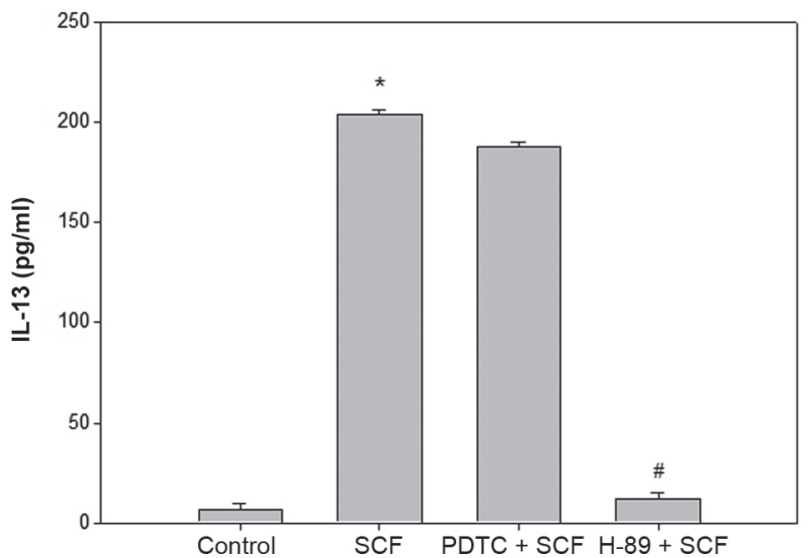

Figure 7. SCF signal promotes the secretion of IL-13 from P815 cells via CREB. P815 cells (cell density, $5 \times 10^{5}$ cells $/ \mathrm{ml}$ ) were seeded in 24 -well plates. After pretreatment for 30 min with $\mathrm{H}-89(20 \mu \mathrm{M})$ or PDTC $(50 \mu \mathrm{M})$, P815 cells were stimulated for $6 \mathrm{~h}$ with SCF $(50 \mathrm{ng} / \mathrm{ml})$, then the content of IL-13 in the culture supernatant of P815 cells was detected by ELISA. 'Control' means P815 cells stimulated with dissolution medium. 'SCF' refers to P815 cells stimulated with $50 \mathrm{ng} / \mathrm{ml} \mathrm{SCF}$. 'PDTC or $\mathrm{H}-89+\mathrm{SCF}$ ' refers to $\mathrm{P} 815$ cells pretreated for $30 \mathrm{~min}$ with $\mathrm{PDTC}$ or $\mathrm{H}-89$, then stimulated with $50 \mathrm{ng} / \mathrm{ml} \mathrm{SCF} .{ }^{*} \mathrm{P}<0.01$ vs. control; ${ }^{\mathrm{P}} \mathrm{P}<0.01$ vs. SCF. IL-13, interleukin 13; SCF, stem cell factor.

SCF activates CREB to promote the production of $I L-13$ in P815 cells. To further clarify the role of the downstream factor of MEK-ERK pathway in SCF promoting the IL-13 production in $\mathrm{P} 815$ cells. After pretreated 30 min with $\mathrm{H}-89$ (20 $\mu \mathrm{M}, \mathrm{CREB}$ blocker) or PDTC (50 $\mu \mathrm{M}, \mathrm{NF}-\kappa \mathrm{B}$ inhibitor), P815 cells were stimulated with SCF $(50 \mathrm{ng} / \mathrm{ml}) 6 \mathrm{~h}$, and the content of IL-13 in supernatant was detected by ELISA (Fig. 7). PDTC had no effect on the SCF promoting P815 cells to produce IL-13, whereas H-89 completely inhibited the effect of SCF.

To demonstrate the activation of CREB, nuclear proteins of P815 cells stimulated $1 \mathrm{~h}$ by SCF $(50 \mathrm{ng} / \mathrm{ml})$ was extracted for EMSA. The results are shown as in Fig. 8. SCF signal induced significant CREB activation in P815 cells. These suggest that SCF signaling can regulate the production of IL-13 in P815 cells by activating transcription factor CREB.



Figure 8. SCF signaling induces the activation of CREB in P815 cells. P815 cells (cell density, $5 \times 10^{5}$ cells $/ \mathrm{ml}$ ) were seeded in 24 -well plates. P815 cells were stimulated for $1 \mathrm{~h}$ with SCF $(50 \mathrm{ng} / \mathrm{ml})$, then nuclear proteins were extracted. The activation of CREB in P815 cells was detected by EMSA. SCF, stem cell factor.

\section{Discussion}

In the present study we demonstrate that there is the presence of c-kit expression on the P815 cells membrane surface, and SCF signaling can induce MEK-ERK-CREB signaling pathway activation in $\mathrm{P} 815$ cells, blocking the pathway inhibits the effect of SCF promoting P815 cells to produce IL-13. 
$\mathrm{SCF}$, also known as c-Kit ligand, is an important growth factor in the body, including soluble and membrane-bound two forms. SCF is mainly produced by fibroblasts and endothelial cells and it can promote the proliferation, migration, survival and differentiation of hematopoietic precursor cells, melanocytes, germ cells and other cells. Studies have indicated that SCF-c-Kit signaling also plays an important role in the survival, growth, adhesion and other biological activities of MCs $(15,16)$. Since MCs play a key role in allergic reactions, SCF-c-Kit signaling is an important research target in the study of allergic reactions. SCF start its effect by binding to c-Kit, the combination of SCF led to $\mathrm{c}-\mathrm{Kit}$ dimerization and open its protein kinase activity. Activation of c-Kit activates multiple intracellular signaling pathways, such as Src kinase, PI3K, PLC- $\gamma$, MAPK and so on $(11,17)$. SCF induced activation of Src family is associated with the gene transcription and chemical chemotaxis of MCs (18). The PI3K pathway activation induced by SCF is associated with the development of MCs (19). MacNeil's results showed that SCF signal induced mast cell to produce IL-6 by P38MAPK and JNK signaling (20). In this study, we found that the SCF signal can activate the MEK-ERK-CREB signaling pathway, and the activation of this pathway is related to the production of IL-13 in MCs. Therefore, activation of each signal pathway induced by SCF is associated with specific biological functions.

Previous studies have suggested that the content of SCF in sputum and alveolar lavage fluid of asthma patients was increased. SCF was strongly correlated with IgE levels and the state of lung function in patients with allergic and non-allergic asthma patients $(21,22)$. But the exact relationship between SCF and asthma is still not very clear. Asthma is a chronic airway inflammation, which involves a variety of cells and cytokines (23). Epidemiological studies have shown that there is an increasing trend in all parts of the world (including China) about the morbidity and mortality of asthma (24). MCs as the key effector cells in asthma, hay fever and other allergic reaction has been known to everyone, but more and more studies show the product of mast cells after activation can regulate the adaptive immune response intensity, duration and dynamics. Mast cells can also be used as immune regulatory cells to play an important role in a variety of biological processes (25). Once activated, MCs can secrete lipid products, cytokines and chemokines three types of chemical media. This study found that the production of IL-13 was increased in mast cells stimulated by SCF signal. Li's results showed that SCF signal induced mast cell to produce IL-13 through the early growth response factor-1 (26), which is consistent with our research results.

IL-13, molecular weight of $12 \mathrm{KDa}$, is a pleiotropic cytokine which regulates IgE synthesis, mucus hypersecretion, subepithelial fibrosis, eosinophil tissue infiltration, chemokine receptors (eg CCR5) expression, which is also closely linked with airway inflammation and bronchial remodeling. Current studies suggest that IL-13 plays a central role in the pathogenesis of asthma $(27,28)$. Thus, SCF signaling may play an important role in the pathogenesis of asthma by affecting the production of IL-13 in mast cells.

In conclusion, this study suggests that SCF signaling can induce mast cells P815 to produce IL-13, and this effect is related to the MEK-ERK-CREB signaling pathway.

\section{Acknowledgements}

Not applicable.

\section{Funding}

The present study was supported by National Science Foundation of China (grant no. 81273273), Anhui Provincial Natural Science Foundation (grant no. 1708085MH218) and the Scientific Research Innovation Team Project of Anhui Colleges and Universities (grant no. 2016-40).

\section{Availability of data and materials}

All data generated or analyzed during the present study are included in this published article.

\section{Authors' contributions}

CS and SG designed the experiments. YW, HM, XT, YL, HW and JH performed the experiments. QF, SG and CS analyzed the data. CS wrote the manuscript. CS and SG revised the manuscript. The manuscript has been read and approved by each author, and all authors believe that the manuscript represents honest work.

\section{Ethics approval and consent to participate}

The present study was approved by the Ethics Committee of Bengbu Medical College.

\section{Patient consent for publication}

Not applicable.

\section{Competing interests}

The authors declare that they have no competing interests.

\section{References}

1. Morita H, Saito H, Matsumoto K and Nakae S: Regulatory roles of mast cells in immune responses. Semin Immunopathol 38: 623-629, 2016.

2. Huang $\mathrm{H}, \mathrm{Li}$ Y and Liu B: Transcriptional regulation of mast cell and basophil lineage commitment. Semin Immunopathol 38: 539-548, 2016.

3. Boeckxstaens G: Mast cells and inflammatory bowel disease. Curr Opin Pharmacol 25: 45-49, 2015.

4. Galli SJ, Nakae S and Tsai M: Mast cells in the development of adaptive immune responses. Nat Immunol 6: 135-142, 2005.

5. Gilfillan AM and Tkaczyk C: Integrated signalling pathways for mast-cell activation. Nat Rev Immunol 6: 218-230, 2006.

6. Arthur G and Bradding P: New developments in mast cell biology: Clinical implications. Chest 150: 680-693, 2016.

7. Cardamone C, Parente R, Feo GD and Triggiani M: Mast cells as effector cells of innate immunity and regulators of adaptive immunity. Immunol Lett 178: 10-14, 2016.

8. Savage JH, Courneya JP, Sterba PM, Macglashan DW, Saini SS and Wood RA: Kinetics of mast cell, basophil and oral food challenge responses in omalizumab-treated adults with peanut allergy. J Allergy Clin Immunol 130: 1123-1129.e2, 2012.

9. Andersson C, Tufvesson E, Diamant Z and Bjermer L: Revisiting the role of the mast cell in asthma. Curr Opin Pulm Med 22: 10-17, 2016

10. Reber L, Da Silva CA and Frossard N: Stem cell factor and its receptor c-Kit as targets for inflammatory diseases. Eur J Pharmacol 533: 327-340, 2006. 
11. Lennartsson J and Rönnstrand L: Stem cell factor receptor/c-Kit: From basic science to clinical implications. Physiol Rev 92: 1619-1649, 2012.

12. Lorentz A and Bischoff SC: Regulation of human intestinal mast cells by stem cell factor and IL-4. Immunol Rev 179: 57-60, 2001

13. Al-Azzam N, Kondeti V, Duah E, Gombedza F, Thodeti CK and Paruchuri S: Modulation of mast cell proliferative and inflammatory responses by leukotriene $\mathrm{d} 4$ and stem cell factor signaling interactions. J Cell Physiol 230: 595-602, 2015.

14. Livak KJ and Schmittgen TD: Analysis of relative gene expression data using real-time quantitative PCR and the 2(-Delta Delta C(T)) method. Methods 25: 402-408, 2001.

15. Faber TW, Pullen NA, Fernando JF, Kolawole EM, McLeod JJ Taruselli M, Williams KL, Rivera KO, Barnstein BO, Conrad DH and Ryan JJ: ADAM10 is required for SCF-induced mast cell migration. Cell Immunol 290: 80-88, 2014

16. Smrž D, Bandara G, Beaven MA, Metcalfe DD and Gilfillan AM: Prevention of F-actin assembly switches the response to SCF from chemotaxis to degranulation in human mast cells. Eur J Immunol 43: 1873-1882, 2013.

17. Stankov K, Popovic S and Mikov M: C-KIT signaling in cancer treatment. Curr Pharm Des 20: 2849-2880, 2014

18. O'Laughlin-Bunner B, Radosevic N, Taylor ML, Shivakrupa, DeBerry C, Metcalfe DD, Zhou M, Lowell C and Linnekin D: Lyn is required for normal stem cell factor-induced proliferation and chemotaxis of primary hematopoietic cells. Blood 98: $343-350,2001$.

19. Fukao T, Yamada T, Tanabe M, Terauchi Y, Ota T, Takayama T, Asano T, Takeuchi T, Kadowaki T, Hata Ji J and Koyasu S: Selective loss of gastrointestinal mast cells and impaired immunity in PI3K-deficient mice. Nat Immunol 3: 295-304, 2002.

20. MacNeil AJ, Junkins RD, Wu Z and Lin TJ: Stem cell factor induces AP-1-dependent mast cell IL-6 production via MAPK kinase 3 activity. J Leukoc Biol 95: 903-915, 2014.
21. Moaaz M, Abo El-Nazar S, Abd El-Rahman M and Soliman E: Stem cell factor and interleukin-31 expression: Association with IgE among Egyptian patients with atopic and Nonatopic bronchial asthma. Immunol Invest 45: 87-106, 2016.

22. Lei Z, Liu G, Huang Q, Lv M, Zu R, Zhang GM, Feng ZH and Huang B: SCF and IL-31 rather than IL-17 and BAFF are potential indicators in patients with allergic asthma. Allergy 63 : 327-332, 2008.

23. Samitas K, Delimpoura V, Zervas E and Gaga M: Anti-IgE treatment, airway inflammation and remodelling in severe allergic asthma: Current knowledge andfuture perspectives. Eur Respir Rev 24: 594-601, 2015.

24. Anandan C, Nurmatov U, van Schayck OC and Sheikh A: Is the prevalence of asthma declining? Systematic review of epidemiological studies. Allergy 65: 152-167, 2010.

25. Bulfone-Paus $\mathrm{S}$ and Bahri R: Mast cells as regulators of $\mathrm{T}$ cell responses. Front Immunol 6: 394, 2015.

26. Li B, Berman J, Tang JT and Lin TJ: The early growth response factor- 1 is involved in stem cell factor (SCF)-induced interleukin 13 production by mast cells, but is dispensable for SCF-dependent mast cell growth. J Biol Chem 282: 22573-22581, 2007.

27. Mitchell J, Dimov V and Townley RG: IL-13 and the IL-13 receptor as therapeutic targets for asthma and allergic disease. Curr Opin Investig Drugs 11: 527-534, 2010.

28. Corren J: Role of interleukin-13 in asthma. Curr Allergy Asthma Rep 13: 415-420, 2013.

(i) (5) This work is licensed under a Creative Commons

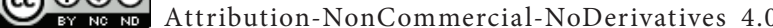
International (CC BY-NC-ND 4.0) License. 